\title{
General Science in the Junior High Schools of Massachusetts
}

\author{
W. G. Whimshax, Nonalal Scrool, Salem, Mass.
}

Superintendents and teachers have long been aware of the unsatisfactory condition of science teaching in the seventh and eighth grades. Here and there an enthusiastic nature-loving superintendent has evolved a helpful science program to meet local needs and the State Law requiring the teaching of physiology has compelled some attention to be given to that subject. But the majority of towns lack in the elementary schools any science courses which are satisfactory either to the pupil or to the teachers. With no definite outline suggesting profitable science work and with no text-books covering this field available, elementary school science has been drifting aimlessly for years.

School programs are frequently made out without including science or nature study except that enough physiology and hygiene are included to meet the State Law and even the law is scarcely met in many schools. 'This omission is not because the superintendent thinks that science is unimportant for nine out of ten superintendents with whom you talk say: "Yes, we ought to have more science in our elementary schools, but we have no teachers who can handle the subject." The chief reason that teachers are shy at teaching science is that they must make out the course, furnish the material, and do the teaching. Few teachers have the time and energy required for this so it is but natural for them to offer objections and to consider it a burden.

-With the development of the junior high school and the readjustment to the program of studies the question of science is receiving renewed attention throughout the country. We find that serious attempts are being made to organize suitalle science material to fill the gap that has existed so long between the nature stndy of the first six grades and the special sciences of the high school. Where no junior high school exists the problem of science in the screnth and eighth grades and the first year of the high school may be the equiv- 
alent of a series of science subjects in the seventh, eighth, and ninth grades of the junior high school.

In order to determine the present status of science work in the various schools of Massachusetts a questionnaire was sent about a year ago to all the superintendents of the State. There were one hundred and eighteen replies. Data were obtained relating to science taught under these heads: Physiology and Hygiene, Nature Study, Elementary Science, and General Science.

The total time given to all science work including physiology, hygiene, elementary or general science, and nature studly from the beginning of the seventh grade through the ninth grade or first year of the high school, is given in Table I. The totals are in week-yearninutes. For example: If a school gives sixty minutes per week to hygiene for a year in grades seven, eight, and nine, and three hundred and twenty minutes per week to general science in the ninth grade for one-half a year the hygiene counts 180 and general science 160 , making a total equivalent to 340 minutes per week for one year or 340 week-ycar-minutes.

Table I. Time Allotment to Science. Grades VII. to IX. in 115 Miassachusetts Schools.

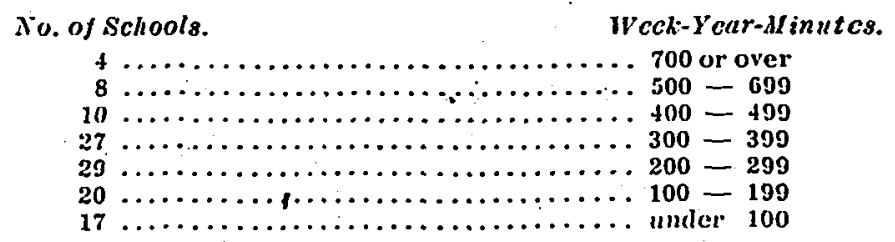

The wide range-from 40 to 740 week-year-minutes-indicates the chaotic condition of the present science teaching in the elementary schools. If we set 500 week-year-minutes as the standard, we see that only $10 \%$ of the schools mect the standard. A standard of 500 week-year-minutes would require about three periods per week in the seventh, fourth periods per week in the eighth, and four periods per week in the ninth grade, each period being 45 minutes in length. This is the time recommended by the Committee on the Junior Figh Schnol for the High School Masters' Cluh of Massachinsetts in their report of March. 191\%. While few data on these grades for other states are available, the time allotment for some schools is at hand and may be used for comparison. Sec T'able II. 
Table II. Time Allotment to Science. Junior High Schools Out$\frac{\text { Kalamazoo Scottville Rochester }}{\text { Three Schools }}$

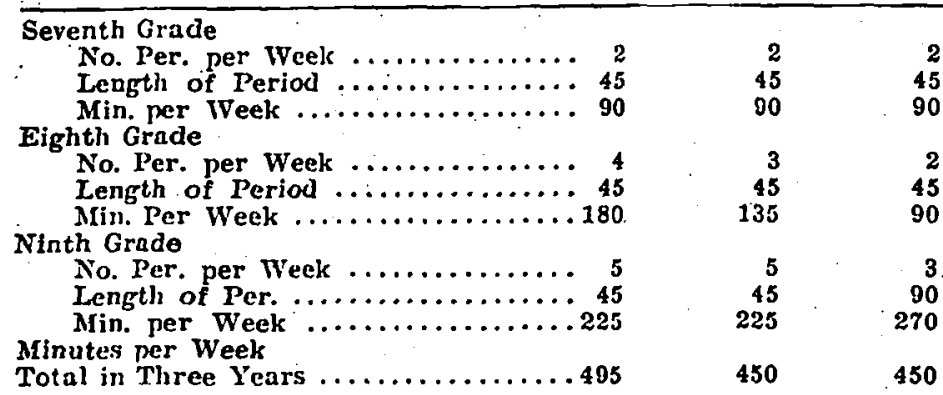

The time given for Kalamazoo and Scottville is all devoted to general science; the writer has no information about how much time in addition is given to physiology and hygiene in these grades.

In Rochester, the first plan was to give general science in the seventh and ninth grades and physiology and hygiene in the eighth grade. This plan has been abandoned and a three years' course in general science adopted. The course inclndes considerable subject matter from the field of physiology and hygiene.

Table III. Time Allotment of Science Studies. Showing Naming and Grouping of Studies as Reported in the Questionnaire Answers.

\begin{tabular}{|c|c|c|}
\hline $\begin{array}{l}\text { Number of } \\
\text { Selinols }\end{array}$ & $\begin{array}{c}\text { Range (min. } \\
\text { per week) }\end{array}$ & $\begin{array}{l}\text { Average (min } \\
\text { per week) }\end{array}$ \\
\hline $\begin{array}{r}\text { Physiology and Ifygiene } \ldots \ldots \ldots \ldots \\
\text { 7th Grade } \ldots \ldots \ldots \ldots \ldots \ldots \ldots \\
\text { 8th Grade } \\
\text { 9th Grade (or 1st. yr. high) } \\
6\end{array}$ & $\begin{array}{l}15=200 \\
25=150 \\
30=200\end{array}$ & $\begin{array}{l}48 \\
50 \\
80\end{array}$ \\
\hline 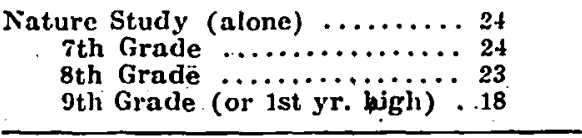 & $\begin{array}{r}10=200 \\
10=150 \\
30-300 \\
\end{array}$ & $\begin{array}{r}58 \\
45 \\
160\end{array}$ \\
\hline 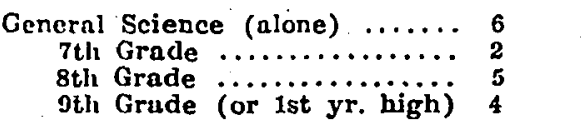 & $\begin{array}{r}20=60 \\
30=250 \\
120-320\end{array}$ & $\begin{array}{r}40 \\
132 \\
218\end{array}$ \\
\hline
\end{tabular}




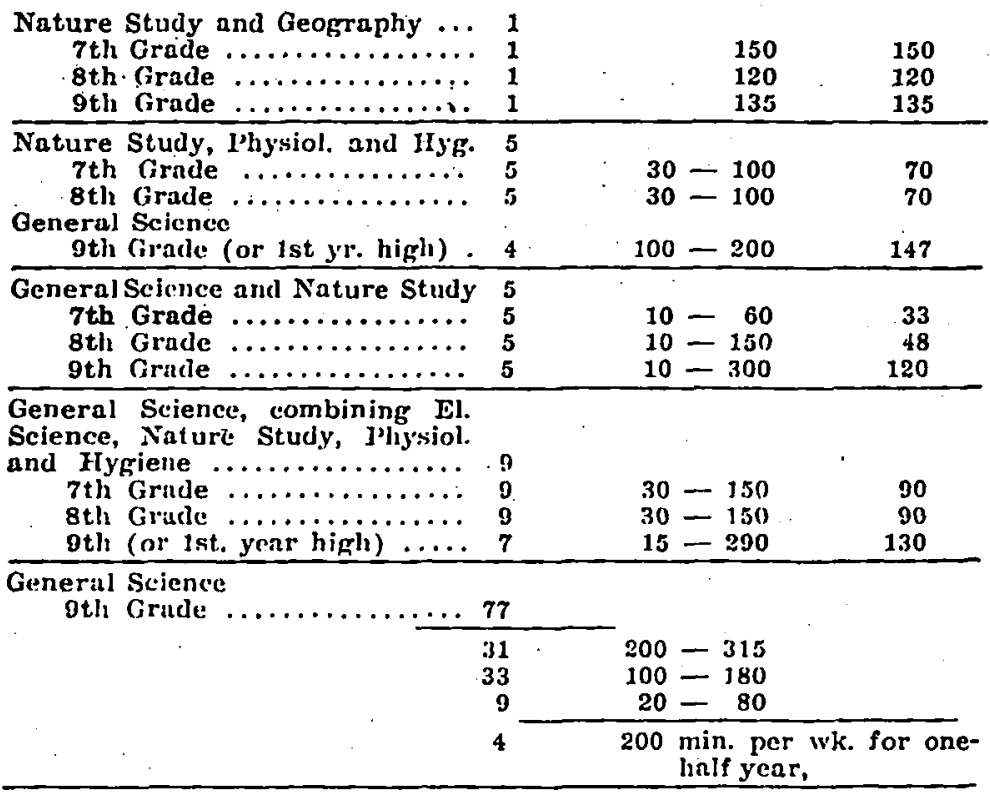

The following statement will suggest the interpretation of Table III. Out of a total of 118 schools, 89 give a course in physiology and hygiene separated from other science work; 87 of these give the work in the seventh grade: The time devoted to it varies from 15 to 200 minutes per week. The average time for the 87 schools is 48 minutes per weck. All of these schools give physiology and hygiene in the eighth grade and 36 of them in the ninth grade.

'Table III. shows as we would expect that physiology and hygiene are taught in more scliools than any other science. But there is not as much time given to them in a single school as is given to nature study or general science where these studies are taught.

At the end of 'Table III. is listed general science for the ninth grade in 77 schools, not included in the other groups of Table III. In these 77 schools there is a wide range in the time given to the subject. It varies from 20 minutes to 315 minutes per week. Is there any good reason why general science should not receive at least 200 minutes per week in this grade?

IVhere physiology and hygiene and general science are given as separate course, there is bound to be much overlapping or from fear of overlapping omissions of valuable material. It has been suggested that it might be advantageous to organize a series of courses in general science running through the seventh, eighth, and ninth 
grades, which should include the physiology, hygiene, nature study, elementary science and general science, which are so often given in fragments. Nine schools report that they are already doing this (see 'Table IIl.). In 1916 a committee of superintendents, working in conjunction with the Commissioner of Education, after consideration of the science problems of the elementary schools, voted to recommend that all science beginning in the seventh grade should be incorporated in and organized as a course in gemeral science, extending through the several years of the school; this general science course is to include the physiology and hygiene.

The attitude of superintendents towards a grouping of all the science into a single general science course is best expressed by quoting their replies giren to two questions of the questionnaire. They were asked to state what objections they could see to such a combination, also to state what adrantages they could see in such a course. 'l'here were 100 who were in favor of one general science course which sluuld combine all the science work. Six objected to the combination and twelve failed to register their preference.

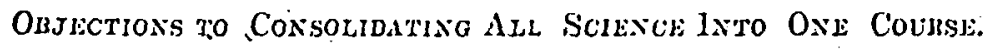

"It will not give enough time to hygiene."

"I feel that hygricne should stund alone or with physiology or physical training."

"The ordinary teacher would make a hopeless hodge-podge of the course unless with a definite outline."

"Only citics and rich towns can get suitable teachers."

"Difficulty of securing competent teachers and proper equipment, especially in the small towns."

"I do not think I would combine hygricne with other science."

"Lack of trained teachers and suitable material."

"Instruction in physiology and hygiene is required by the State.

"Better combine them with physical training."

"Mrust be in the lands of skilful teachers."

"Chiefly the dilliculty of trying to cover too much ground with inmature children and teachers imt rivined in the subject."

"I do not see how it can be done within the time limits of the school day."

"Incapacity of teachers. Lack of suitable texts."

"Might result in too little attention to physiology and personal hygienc."

"Difficulty of getting a teacher with the right point of view."

"Usually such combinations run to hodge-podge."

The majority of those who offered objections to the proposed plan roted in favor of it. 
Advantages of Consolidating At, Science Into One Course. "Correlation" (4) "Economy of time." (6).

"Would cconomize time and give better opportunity for correlation." (6).

"Saving of time both in preparation and in class work on part of teacher: More concentrated 'Food' for pupils."

"Saving of time and energy both for teacher and pupils."

"Elimination of duplicate material. Simplification of schedule."

"Some saving of time, better" correlation, opportunity for first-hand obscrvation."

"Interrelations would be made clearer. The subjects as a new unit would received merited attention more than at present incidentally."

"flime saver, deliniteness secured, becomes a unit with aims."

"Better work and a saving of time."

"Correlation of matter and simplification of program."

"It would condense the work of the teacher and simplify the program."

"Uniformity, concentration, snving time, better teaching, and added importance to the subjects combined in the course."

"Excellent plan, it would tend towards less recitation periods."

"Ilie work would be more systematic in all schools." .

"Similar to our plan." "More concentration."

"The sciences are related and by taking them together as a definite course there is more freedom for consideration of real projects, and the course of study and program can be more definite."

"Uniformity, definite sequence."

"Bctter aims and methods."

"Good idlen." "A good thing." " $A$ good irlen."

"I would heartily welcome such a plan. Its advantages are definiteness, system, a claim to recognition."

"Very desirable. Better organization of science work. Broader treatment."

"Accumulated interest and knowlelge. $\Lambda$ saving of time."

"Subjects will he more generally taught througliout the state."

"Will make it much easier for my rural teachers to arrange their program."

"A more definite space of time would be given."

"More likely to get definite results, especially when teacliers are often_changing."

"It would insure the teaching of certain subjects now neglected."

"When the course is properly adjusted it will constitute a unit."

"It is what we are planning to do."

"Gives continuity and articulates more closely. Lays the founda-

tion in a brond field of very useful and necessary knowledge."

"That is cssentially what we are now doing."

"Fine iden, wish I had such a course."

"Continuous interest. Unity.". 
"It might make an important subject from three or four unimportant ones and give the essentials of each co-related to each other, and adapted to pupil students."

"Would systematize this work.' Give us a workable course for all schools."

"Probability of getting time for attention to cacll of these sub-divisions which would not be alotted to them separately."

"Insufficient time for separate continuous courses. Combined, emphasis can be given to different phases of the work at different times."

"Assures it a regular place in the curriculum."

"Will bring together work that should be organized together."

"More concentration, better instruction."

"It would tend to check our tendency toward infinite sub-division of subjects."

"Opportunity to vary the emphasis as needed." And to make the work continuous through the three years, seventh, eighth, and ninth grades."

"Helps teachers to appreciate relation of subjects and hence gives a better perspective to pupil."

"Properly tauglıt it should open up to the child new interests that are at present neglected."

"More general knowledge, more helpful work in observation, greater cleanliness at home as wcll as at schiool."

"The child may bave the instruction he neels when it will be of most value to him."

"Better preparation of our pupils for High School."

"Some knowledge of science for those who can not go to the $\mathrm{High}$ School."

"Many advantages if the common problems of the household aretaken up."

"If well presented with a good text-book I think we should accomplish the work much better than now."

"We do this already."

"It would tend to correct the point. of view of the ordinary teachers and break up the tendency to routine."

"More attention given to science and more work."

"As term implies Geneml Science should include all sciences."

"The interrelating of these subjects malies it cxpedient to combine them. The opportunity of the teacher to explore the field of science without overlapping other subject matter is an advantage."

"Each helps the other." "Unity of subjects."

"Anything that will systematize and unify the work would ${ }^{-} \overline{b e}$ an advantage."

"Think it an admirable scheme." "Trill economize time and energy." "Arouse interest in nature. Conserve nature's resources." 
"Everything to its advantage. Something definite, that can receive its share of each day's time."

"NIore flexibility." "Systematizations."

"More variety of work which I think good."

"It is valuable for those who go no further than the eighth grade."

"A good foundation for later science work."

"Pupils in the grades learn more by having a variety."

"IIore complete and logical instruction."

"Training in clear thinking. Introduction to scientific experimentation and description. Correct life habits based upon well ascertained facts."

'These reports from superintendents indicate three important facts. First: There is uttcr lack of uniformity of practice in science instruction in grades $\dot{7}, 8$, and 9 . Sccond: The cause of the present weakness in elementary school science is due to the lack of qualified teachers and a suitable test. Third: Superintendents are almost unanimous in their desire to have a rather definite outline of suggestive science work for these grädes and that it shall be organized so as to include the physiology and hygiene as well as nature study, elementary and general science.

'I'o meet the demands and immedinte needs, a rather extensive and suggestive outline of a science program for grades 7,8 , and 9 shoull be prepared. The normal schools should prepare teachers qualified to teach such a program of general science. With these two things lone, the other failings of science will largely be remored.

The jumior high school offers a favorable school organization for the developmenit of a general science program. Out of 117 schools reporting 31 alrealy have junior high schools and 35 others expect to have them soon. Almost half the towns and cities have one or more junior high schools now or contemplate having them soon. With prospects of a continued growth of the junior high school idea, it scems reasonable for us to prepare our science program with this school in mind and to prepare a three year plan.

\section{The Making of a Match : a Project}

\section{Cirahias H. Stone, Javglisir Higm Scrood, Boston, Mass.}

Iow much the progress of civilization owes to the use of fire, a moment's reflection will show. Without fire, our steamships and railroad trains must ccase, mills and factories must shut. down, cooking and henting in the home would become impossible. To a 